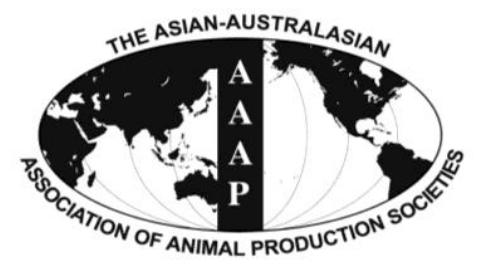

Asian-Aust. J. Anim. Sci.

Vol. 26, No. 4 : 596-602 April 2013

http://dx.doi.org/10.5713/ajas.2012.12580

www.ajas.info

pISSN 1011-2367 elSSN 1976-5517

\title{
Synergistic Effects of Electron-beam Irradiation and Leek Extract on the Quality of Pork Jerky during Ambient Storage
}

\author{
Hyun-Joo Kim, Mingu Kang, Hae In Yong, Young Sik Bae, Samooel Jung and Cheorun Jo* \\ Department of Animal Science and Biotechnology, Chungnam National University, Daejeon 305-764, Korea
}

\begin{abstract}
To investigate the synergistic effect(s) of electron-beam (EB) irradiation and leek (Allium tuberosum Rottler) extract on the quality of pork jerky during ambient storage, we irradiated prepared pork jerky samples (control and samples with $0.5 \%$ and $1.0 \%$ leek extract) with EB technology at doses of $0,1,2$, and $4 \mathrm{kGy}$, stored them for 2 months at $25^{\circ} \mathrm{C}$, and analyzed them. Water activity was 0.73 to 0.77 in non-irradiated samples, and no significant difference in the water activity was observed between the samples treated with leek and the control. The total aerobic bacterial count was significantly decreased with an increase in the irradiation dose and leek extract addition when compared to that of the control $\left(4.54 \pm 0.05 \log\right.$ CFU/g). Further, the Hunter color values $\left(\mathrm{L}^{*}\right.$, $\mathrm{a}^{*}$, and $\left.\mathrm{b}^{*}\right)$ were found to be significantly decreased following leek extract addition and EB irradiation. However, the color values, especially the $\mathrm{a}^{*}$ value of the irradiated samples significantly increased during storage. Notably, increasing the EB irradiation dose enhanced the peroxide value. Sensory evaluation revealed that irradiation decreased flavor and overall acceptability. Our findings suggest the use of EB irradiation in combination with leek extract to improve the microbiological safety of pork jerky. However, in order to meet market requirements, novel methods to enhance the sensory quality of pork jerky are warranted. (Key Words: Pork Jerky, Electron Beam Irradiation, Leek Extract, Quality)
\end{abstract}

\section{INTRODUCTION}

Jerky is one of the most popular meat products that are preserved by salting and drying. Jerky requires a relatively simple preparation process, has a typical flavor, and needs no refrigeration during commercial distribution due to its low water activity. In addition to having a high nutritional value, it can remain shelf-stable for a long time, due to which it is still in high demand in many countries (Calicioglu et al., 2003; Yang et al., 2009). Despite the low moisture content, microbiological safety is of particular concern during marketing and distribution (Park et al., 2009).

Several outbreaks of food-borne illnesses caused by Salmonella in beef jerky (USDA/FSIS, 2003) and by Escherichia coli O157:H7 in venison jerky (Keene et al., 1997) have been reported. Levine et al. (2001) reported the cumulative prevalence rates of Salmonella and Listeria monocytogenes in jerky from federally inspected plants between 1990 and 1999 to be $0.31 \%$ and $0.52 \%$,

\footnotetext{
* Corresponding Author: Cheorun Jo. Tel: +82-42-821-5774, Fax: +82-42-825-9754, E-mail: cheorun@cnu.ac.kr Submitted Oct. 16, 2012; Accepted Dec. 11, 2012; Revised Dec. 17, 2012
}

respectively. In addition, beef jerky has been recalled due to L. monocytogenes contamination detected through routine sampling conducted by processors or regulators (LobatonSulabo et al., 2011).

In the last decade, several single-agent disinfection techniques have been proposed to reduce microorganisms in jerky. These techniques included drying (Han et al., 2007), packaging (Lobaton-Sulabo et al., 2011), and irradiation (Kim et al., 2010). However, most of them were less effective in controlling microorganisms and resulted in quality changes. Therefore, this necessitates the development of highly effective novel techniques in order to improve the safety and quality of jerky, for their use in the meat and meat-processing industries.

Many previous studies evaluating the efficacy and the microbiological safety of different foods, such as meat products and shrimp, have reported the use of different agents in combination (Chawla et al., 2006; Kanatt et al., 2006). Various extracts from spices and herbs containing antibacterial compounds used in combination with irradiation treatments have been shown to possess synergistic effects (Oussalah et al., 2007). Ouattara et al. (2001) have demonstrated that synergistic effects could effectively inhibit microorganisms even at low irradiation 
dose, thus minimizing irradiation-induced quality changes. Recently, Yun et al. (2011) showed that leek extract when used in combination with gamma irradiation effectively inhibited growth of $E$. coli inoculated in pork. However, very few studies have examined the synergistic effects of electron beam (EB) irradiation and natural plant extracts on pork jerky.

In view of the above, the objective of the present study was to investigate the synergistic effect(s) of EB irradiation and leek extract on the microbiological, physicochemical, and sensorial qualities of pork jerky during ambient storage.

\section{MATERIAL AND METHODS}

\section{Sample preparation}

Pork loins and leeks were purchased from a local market in Daejeon, Korea. The pork loins were trimmed of all visible fat, and subsequently sliced to $0.7 \mathrm{~cm}$ thick pieces using a meat slicer (HFS 350G, Hankook Fugee Industries Co. Ltd., Seoul, Korea). The pork chops were marinated at $4^{\circ} \mathrm{C}$ for $12 \mathrm{~h}$ in a jerky curing solution (w/w) with the following composition: water $(10 \%)$, soy sauce $(10 \%)$, starch syrup (7\%), sugar (5\%), D-sorbitol $(6 \%)$, ginger powder $(0.1 \%)$, garlic powder $(0.2 \%)$, onion powder $(0.2 \%)$, potassium sorbate $(0.1 \%)$, pepper $(0.3 \%)$, and/ or leek extract $(0.5 \%$, and $1 \%)$.

Fresh leeks were washed with tap water and sliced to approximately $10 \mathrm{~cm}$ thick pieces. The homogeneous leek sample was extracted with $70 \%$ ethyl alcohol at room temperature for $72 \mathrm{~h}$, followed by evaporation of the solvent. The extract was then lyophilized (TFD5505, Ilshin Lab Co. Ltd., Korea) to obtain powder. Ethyl alcohol extracts were shown to possess maximum antimicrobial activity, and the corresponding extraction procedure was considered to be the most effective amongst the different preparation methods for obtaining leek extract (Yun et al., 2011).

Cured meat was sequentially dried using a convection oven (JSOF-150; JS Research Inc., Korea) at $75^{\circ} \mathrm{C}, 65^{\circ} \mathrm{C}$, and $55^{\circ} \mathrm{C}$ for $150 \mathrm{~min}, 90 \mathrm{~min}$, and $60 \mathrm{~min}$, respectively. After cooling, the jerky samples were packaged under vacuum conditions.

\section{EB irradiation}

Each prepared sample was irradiated on either sides in a linear EB RF accelerator (Energy 2.5 MeV, beam power 40 kW, EB Tech., Daejeon, Korea). The beam current was 0 to $4.5 \mathrm{~mA}$. Irradiation was performed with a conveyor velocity of $10 \mathrm{~m} / \mathrm{min}$ and a dose rate of 1.1 to $4.4 \mathrm{kGy} / \mathrm{s}$. Because the incident $\mathrm{EB}$ had a low penetration power, all the samples were irradiated to $0.7 \mathrm{~cm}$ of thickness for enhancing the effectiveness of irradiation. To confirm the target dose, alanine dosimeters attached to the top and bottom surfaces of the sample pack were read using a 104
Electron Paramagnetic Resonance unit (EMS-104; Bruker Instruments Inc., Bullerica, MA). The calculated maximum/minimum dose ratio was less than 1.004 for all the samples. The doses employed in this study were $0,1,2$, and $4 \mathrm{kGy}$. After irradiation, the samples were immediately stored under commercial storage conditions at $25^{\circ} \mathrm{C}$, until further analysis.

\section{Water activity}

The samples in which water activity had to be measured were minced into pieces of approximately $2 \times 2 \mathrm{~cm}$ in size. The water activity of each sample was determined in triplicate using LabMASTER-Aw system (Novasina AG, Lachen, Switzerland).

\section{Microbiological analysis}

After irradiation, each sample (5 g) was cut into small pieces (approximately $0.5 \times 0.5 \mathrm{~cm}$ ) and homogenized for 2 min in a sterile stomacher bag containing $45 \mathrm{ml}$ of sterile saline $(0.85 \%)$ by using a stomacher (bag mixer ${ }^{\circledR} 400$; Interscience Co., France). Subsequently, the homogenized samples were serially diluted in sterile saline $(0.85 \%)$ and were plated by spreading $0.1 \mathrm{ml}$ on a total plate count agar (Difco Laboratories, Detroit, MI, USA) and eosin methylene blue agar (EMB; Difco) for total aerobic bacteria counts and total coliform counts, respectively. Plates were then incubated at $37^{\circ} \mathrm{C}$ for $48 \mathrm{~h}$. For enumerating mold count, molds were plated onto YM agar (plus $10 \%$ citric acid, $\mathrm{pH}$ 3.6, Difco Laboratories), and the plates were incubated for $5 \mathrm{~d}$. The number of colonies was counted and expressed as colony forming units per gram $(\mathrm{CFU} / \mathrm{g})$.

\section{Color measurement}

Color of the pork jerky sample surface was evaluated using a Color Difference Meter (Spectrophotometer CM3500d, Konica Minolta Sensing, Inc., Osaka, Japan), and Hunter color values, L* (lightness), a* (redness), and $b^{*}$ (yellowness) were determined. The instrument was calibrated to standard black and white plate before analysis. The Hunter values were monitored by a computerized system using spectra magic software (Konica Minolta Sensing, Inc., Japan) and the measurements were performed in triplicate.

\section{Peroxide value (POV)}

Lipid extraction was performed according to Folch extraction method (Folch et al., 1957). Each sample (10 g) was cut into small pieces and placed in a glass vial containing $50 \mathrm{ml}$ Folch solution (chloroform:methanol, 2:1). The samples were stirred at room temperature for $24 \mathrm{~h}$. Subsequently, the mixture was filtered using a filter paper (Whatman No. 4, Whatman Ltd., Maidstone, England) and $15 \mathrm{ml} \mathrm{NaCl}(0.88 \%)$ was added. After shaking vigorously, 
$10 \mathrm{ml}$ was collected from the bottom layer and evaporated under a stream of nitrogen gas, leaving the extracted lipids for POV analysis. The lipid sample was treated with $35 \mathrm{ml}$ of solvent mixture (acetic acid:chloroform, 3:2) and shaken thoroughly, after which $0.5 \mathrm{ml}$ of saturated potassium iodide solution was added. The mixture was kept in dark for $5 \mathrm{~min}$; $75 \mathrm{ml}$ of distilled water was added followed by vigorous mixing. Soluble starch solution in phosphate buffer $(2.5 \mathrm{ml}$, $1 \%[\mathrm{w} / \mathrm{v}])$ was employed as an indicator. The peroxide value was determined by titrating the iodine liberated from potassium iodide using standardized $0.005 \mathrm{~N}$ sodium thiosulfate solutions. The POV was calculated by the following equation.

$$
\mathrm{POV}(\mathrm{meq} / \mathrm{kg})=\left[\left(\mathrm{V}_{1}-\mathrm{V}_{0}\right) \times \mathrm{F} \times 0.01 / \mathrm{S}\right] \times 1,000
$$

$\mathrm{V}_{1}$ : titration amount $(\mathrm{ml})$ of $0.005 \mathrm{~N} \mathrm{Na}_{2} \mathrm{~S}_{2} \mathrm{O}_{3}$ on the samples.

$\mathrm{V}_{0}$ : titration amount $(\mathrm{ml})$ of $0.005 \mathrm{~N} \mathrm{Na}_{2} \mathrm{~S}_{2} \mathrm{O}_{3}$ on the blank.

F: factor of $0.005 \mathrm{~N} \mathrm{Na}_{2} \mathrm{~S}_{2} \mathrm{O}_{3}$ solution.

$\mathrm{S}$ : sample weight $(\mathrm{g})$.

\section{Sensory evaluation}

Sensory evaluation was performed by 10 panelists who had a previous experience of analyzing irradiation off-odor and the pork jerky quality, while carrying out different studies related to food irradiation. Jerky samples treated with $1 \mathrm{kGy}$ were omitted from sensory evaluation due to their incomplete microbial inhibitory ability when compared to doses of 2 and $4 \mathrm{kGy}$. Further, this prevents the panelists from getting confused with a large number of samples. Samples were assessed for their color, flavor, texture, juiciness, overall acceptability, and irradiation offodor. A 7-point hedonic scale, where 7 implies extreme like and 1 implies extreme dislike, was employed for evaluating all the qualities, except off-odor. Off-odor was assessed as follows: 7 , very strong; and 1, no off-odor. The samples were placed on a transparent plastic dish and labeled randomly by assigning a 3-digit numerical code. All samples were provided to each of the panelists along with drinking water for rinsing their oral cavity following the testing of every sample. This procedure of sensory evaluation was conducted thrice independently.

\section{Statistical analyses}

The data were analyzed using SAS software (Release 8.01, SAS Institute, Inc., Cary, NC, USA). Statistical analysis was performed by one-way analysis of variance (ANOVA). When significant differences were detected, the differences among the mean values were determined by Duncan's multiple comparison test at a confidence level of $\mathrm{p}<0.05$. Mean values and standard errors of the mean are
Table 1. Water activity (Aw) of the electron beam irradiated pork jerky with added leek extract

\begin{tabular}{llll}
\hline $\begin{array}{c}\text { Irradiation dose } \\
(\mathrm{kGy})\end{array}$ & 0 & 0.5 & 1.0 \\
\cline { 2 - 4 } & 0.760 & $0.767^{\mathrm{a}}$ & 0.730 \\
0 & 0.702 & $0.701^{\mathrm{b}}$ & 0.702 \\
1 & 0.706 & $0.703^{\mathrm{b}}$ & 0.700 \\
2 & 0.709 & $0.704^{\mathrm{b}}$ & 0.687 \\
4 & 0.026 & 0.016 & 0.022 \\
SEM $^{1)}$ &
\end{tabular}

${ }^{a-b}$ Means within the same column with different superscript differ significantly $(\mathrm{p}<0.05)$.

${ }^{1}$ Standard errors of the mean $(n=12)$.

reported.

\section{RESULTS AND DISCUSSION}

\section{Water activity}

When manufacturing intermediate moisture foods such as jerky, it is necessary to control water activity (Leistner, 1987). In this study, the water activity (Aw) was 0.730 to 0.767 in non-irradiated samples, and no significant difference in the water activity was observed between the samples treated with leek and the control (Table 1). Yang and Lee (2002) reported the water activity of commercial pork jerky to be 0.743 in Korea market. Chen et al. (2002) stated that Chinese-style pork jerky product has a water activity of approximately 0.75 and was the most popular traditional Chinese meat item in Taiwan. Water activity is useful to describe the thermodynamic equilibrium state of jerky (Labuza, 1980; Rockland and Nishi, 1980), and foods such as jerky must have a stable water activity to avoid changes in quality during storage (Yamaguchi et al., 1986).

\section{Microbiological examination}

The results obtained from the microbiological analyses of the combinatorial treatment of pork jerky during storage are shown in Table 2. The total aerobic bacterial count was significantly decreased with an increase in the irradiation dose and leek extract addition when compared to that of the control (4.54 $\pm 0.05 \log \mathrm{CFU} / \mathrm{g})$. The number of bacterial colonies increased with an increase in storage duration. On the contrary, the addition of leek extract had an inhibitory effect on the growth of total aerobic bacterial populations when compared to the control that lacked the extract. Notably, there was no viable cell growth of microorganisms in the jerky sample when treated at $4 \mathrm{kGy}$. In addition, mold and coliform bacterial populations were not detected in pork jerky in this study (data not shown). Consistent with the results of a previous study, irradiation resulted in maximal inactivation of microorganisms in pork jerky (Kim et al., 2010).

In recent years, there has been an increasing interest 
worldwide in employing hurdle approaches to enhance the shelf life of perishable foods, especially meat products, while simultaneously ensuring the microbiological safety of these products during food production and processing (Park et al., 2012). Radiation is regarded as the most widely accepted physical method for sterilization because it is simple and rapid, and results in an effective reduction of microorganisms. The bactericidal effect of irradiation, including $\mathrm{EB}$ is due to the production of oxygen and hydroxyl radicals, which damage the DNA of microorganisms.

On the other hand, plant extracts that have been approved and qualified to be Generally Recognized as Safe (GRAS) substances are being widely used in the food industry (Ahn et al., 2007). Plant extracts constitute several small terpenoid and phenolic compounds with potent antimicrobial activity that could be attributed to their lipophilic nature, which aids in their accumulation in the bacterial membranes and thus induce energy depletion (Conner, 1993; Yun et al., 2011). Leek, a member of the genus Allium, is known to have potent antioxidative properties against several microorganisms due to the presence of a high amount of total polyphenol compounds (Ahn et al., 2005). Therefore, in line with the previous studies, the present study established the combinatorial treatment of EB irradiation with leek extract as an additional hurdle, to be an effective microbial decontamination method for pork jerky.

\section{Color measurement}

The color changes in pork jerky during storage are shown in Table 3. Notably, the Hunter color values of $a^{*}$
Table 2. Total aerobic bacterial counts $(\log \mathrm{CFU} / \mathrm{g})$ of the electron beam irradiated pork jerky with added leek extract during storage for 2 months

\begin{tabular}{|c|c|c|c|}
\hline \multirow{2}{*}{$\begin{array}{l}\text { Irradiation dose } \\
(\mathrm{kGy})\end{array}$} & \multicolumn{3}{|c|}{ Leek extract $(\%)$} \\
\hline & 0 & 0.5 & 1.0 \\
\hline & -------- & 0 month & ------- \\
\hline 0 & $4.54^{\mathrm{a}}$ & $4.43^{\mathrm{a}}$ & $4.40^{\mathrm{a}}$ \\
\hline 1 & $3.25^{\mathrm{b}}$ & $3.19^{\mathrm{b}}$ & $3.11^{\mathrm{b}}$ \\
\hline 2 & $2.81^{\mathrm{c}}$ & $2.74^{\mathrm{c}}$ & $1.97^{\mathrm{c}}$ \\
\hline 4 & $\mathrm{ND}^{2, \mathrm{~d}}$ & $\mathrm{ND}^{\mathrm{d}}$ & $\mathrm{ND}^{\mathrm{d}}$ \\
\hline SEM $^{1}$ & 0.034 & 0.035 & 0.034 \\
\hline 0 & $4.78^{\mathrm{a}}$ & $\begin{array}{r}1 \text { month } \\
4.55^{\mathrm{a}}\end{array}$ & $4.49^{\mathrm{a}}$ \\
\hline 1 & $3.48^{\mathrm{b}}$ & $3.42^{\mathrm{b}}$ & $3.29^{\mathrm{b}}$ \\
\hline 2 & $3.10^{\mathrm{c}}$ & $3.05^{\mathrm{c}}$ & $2.10^{\mathrm{c}}$ \\
\hline 4 & $\mathrm{ND}^{\mathrm{d}}$ & $\mathrm{ND}^{\mathrm{d}}$ & $\mathrm{ND}^{\mathrm{d}}$ \\
\hline SEM $^{1}$ & 0.011 & 0.023 & 0.027 \\
\hline 0 & $4.98^{\mathrm{a}}$ & $\begin{array}{r}2 \text { month } \\
4.64^{\mathrm{a}}\end{array}$ & $4.55^{\mathrm{a}}$ \\
\hline 1 & $3.66^{\mathrm{b}}$ & $3.48^{\mathrm{b}}$ & $3.37^{\mathrm{b}}$ \\
\hline 2 & $3.25^{\mathrm{c}}$ & $3.12^{\mathrm{c}}$ & $2.27^{\mathrm{c}}$ \\
\hline 4 & $\mathrm{ND}^{\mathrm{d}}$ & $\mathrm{ND}^{\mathrm{d}}$ & $\mathrm{ND}^{\mathrm{d}}$ \\
\hline SEM $^{1}$ & 0.017 & 0.015 & 0.039 \\
\hline
\end{tabular}

${ }^{1}$ Standard errors of the means $(\mathrm{n}=12)$

${ }^{2}$ Viable colony was not detected at detection limit $<10^{1} \mathrm{CFU} / \mathrm{g}$.

${ }^{\text {a-d }}$ Values with different letters within the same row differ significantly $(\mathrm{p}<0.05)$.

increased significantly with an increase in the irradiation dose. However, the a* color values of the samples treated with irradiation were not consistent during storage. Nam et al. (2006) reported that the color of the turkey breast sample turned pink upon irradiation due to the formation of carbon

Table 3. Hunter color value of the electron beam irradiated pork jerky with added leek extract during storage for 2 months

\begin{tabular}{|c|c|c|c|c|c|c|c|c|c|c|}
\hline \multirow{3}{*}{$\begin{array}{l}\text { Leek } \\
\text { extract } \\
(\%)\end{array}$} & \multirow{3}{*}{$\begin{array}{c}\text { Irradiation } \\
\text { dose } \\
(\mathrm{kGy})\end{array}$} & \multicolumn{9}{|c|}{ Storage period (month) } \\
\hline & & \multicolumn{3}{|c|}{0} & \multicolumn{3}{|c|}{1} & \multicolumn{3}{|c|}{2} \\
\hline & & $\mathrm{L}^{*}$ & $a^{*}$ & $\mathrm{~b}^{*}$ & $\mathrm{~L}^{*}$ & $a^{*}$ & $\mathrm{~b}^{*}$ & $\mathrm{~L}^{*}$ & $a^{*}$ & $\mathrm{~b}^{*}$ \\
\hline \multirow[t]{5}{*}{0} & 0 & 33.59 & $7.89^{b}$ & $13.32^{\mathrm{b}}$ & $33.74^{\mathrm{a}}$ & 9.51 & 15.61 & 26.65 & $7.96^{\mathrm{b}}$ & 9.52 \\
\hline & 1 & 35.65 & $9.45^{\mathrm{a}}$ & $16.52^{\mathrm{a}}$ & $30.59^{\mathrm{b}}$ & 9.05 & 13.80 & 30.55 & $9.72^{\mathrm{a}}$ & 12.71 \\
\hline & 2 & 34.03 & $9.08^{\mathrm{a}}$ & $14.70^{\mathrm{ab}}$ & $32.09^{\mathrm{ab}}$ & 9.26 & 14.69 & 29.98 & $9.66^{\mathrm{a}}$ & 12.94 \\
\hline & 4 & 33.96 & $8.97^{\mathrm{a}}$ & $14.98^{\mathrm{ab}}$ & $30.82^{\mathrm{b}}$ & 9.64 & 14.15 & 27.21 & $8.13^{\mathrm{b}}$ & 10.10 \\
\hline & SEM $^{1}$ & 0.952 & 0.233 & 0.893 & 0.773 & 0.360 & 0.633 & 1.752 & 0.366 & 1.579 \\
\hline \multirow[t]{5}{*}{0.5} & 0 & 28.53 & $7.78^{\mathrm{bc}}$ & $11.23^{\mathrm{b}}$ & $31.31^{\mathrm{ab}}$ & $10.41^{\mathrm{a}}$ & $15.70^{\mathrm{a}}$ & 26.47 & $7.07^{\mathrm{c}}$ & 10.30 \\
\hline & 1 & 30.71 & $9.38^{\mathrm{a}}$ & $14.21^{\mathrm{a}}$ & $27.08^{\mathrm{b}}$ & $7.83^{\mathrm{b}}$ & $10.31^{\mathrm{b}}$ & 27.15 & $8.87^{\mathrm{ab}}$ & 12.53 \\
\hline & 2 & 30.64 & $8.31^{\mathrm{b}}$ & $13.94^{\mathrm{a}}$ & $32.35^{\mathrm{a}}$ & $9.67^{\mathrm{ab}}$ & $15.59^{\mathrm{a}}$ & 25.91 & $7.74^{\mathrm{bc}}$ & 10.76 \\
\hline & 4 & 29.62 & $7.36^{\mathrm{c}}$ & $12.21^{\mathrm{ab}}$ & $28.36^{\mathrm{ab}}$ & $9.11^{\mathrm{ab}}$ & $12.83^{\mathrm{ab}}$ & 26.70 & $9.34^{\mathrm{a}}$ & 12.47 \\
\hline & SEM $^{1}$ & 0.915 & 0.193 & 0.726 & 1.502 & 0.586 & 1.280 & 0.737 & 0.428 & 0.839 \\
\hline \multirow[t]{5}{*}{1.0} & 0 & 28.61 & $6.08^{c}$ & 10.91 & $33.47^{\mathrm{a}}$ & 9.12 & $16.55^{\mathrm{a}}$ & $27.58^{\mathrm{ab}}$ & $8.00^{\mathrm{b}}$ & 12.13 \\
\hline & 1 & 30.87 & $7.59^{\mathrm{b}}$ & 12.63 & $29.62^{b}$ & 9.63 & $14.70^{\mathrm{ab}}$ & $29.81^{\mathrm{a}}$ & $7.94^{\mathrm{b}}$ & 12.36 \\
\hline & 2 & 29.46 & $8.27^{\mathrm{a}}$ & 12.05 & $28.05^{\mathrm{b}}$ & 9.05 & $12.52^{\mathrm{c}}$ & $28.48^{\mathrm{ab}}$ & $9.09^{\mathrm{a}}$ & 13.69 \\
\hline & 4 & 29.72 & $8.63^{\mathrm{a}}$ & 12.25 & $30.00^{\mathrm{b}}$ & 8.52 & $13.87^{\mathrm{bc}}$ & $26.42^{\mathrm{b}}$ & $7.02^{c}$ & 10.24 \\
\hline & SEM $^{1}$ & 1.343 & 0.191 & 1.355 & 0.995 & 0.362 & 0.593 & 0.849 & 0.229 & 1.054 \\
\hline
\end{tabular}

\footnotetext{
${ }^{\mathrm{a}-\mathrm{c}}$ Means within the same column with different superscript differ significantly $(\mathrm{p}<0.05)$.
}

${ }^{1}$ Standard errors of the mean $(\mathrm{n}=12)$. 
monoxide-myoglobin complex, which was induced by the production of carbon monoxide and reducing conditions by irradiation. The mechanisms of color changes in irradiated turkey breast could be similarly applied to color changes of the irradiated pork jerky.

Upon addition of the leek extract, the Hunter color values, $\mathrm{L}^{*}$ and $\mathrm{b}^{*}$ of the pork jerky samples showed a decreasing trend following EB irradiation. However, the color values of the samples following by the addition of leek extracts showed inconsistent results during storage. Our findings are in line with those of previous studies, which showed a decrease in the color values of jerky following leek extract addition, and further attributed the changes to the dark green color of the extract (Lim et al., 2009; Cho, 2010).

\section{Peroxide value (POV)}

Although lipid hydroperoxides are the primary products of lipid oxidation, they are in turn converted to peroxides. Therefore, it seemed reasonable to determine the concentration of peroxides in the pork jerky samples to study the extent of oxidation (El-Alim et al., 1999). Peroxide values (POV) of the pork jerky samples treated with EB irradiation and leek extract are presented in Figure 1. Increasing the dose of EB irradiation was found to increase the POV. Our results are in accordance with those of earlier studies, which have demonstrated that irradiation increased lipid oxidation in meat products by producing hydroxyl radicals formed mainly due to water radiolysis (Quattara et al., 2002; Nam et al., 2006).

In this study, POV was found to be higher in irradiated samples. POV of fresh meat are higher than $5 \mathrm{mEq} / \mathrm{kg}$, where the lipid hydroperoxides would have already reacted with oxygen to form secondary oxidation products. A POV between 5 and $10 \mathrm{mEq} / \mathrm{kg}$ implies oxidative rancidity (Javanmard et al., 2006). In the present study, the POV of the samples following the addition of leek extract was higher than the POV of the control prior to storage, although there was no significant difference between the amounts of leek extracts added $(0.5 \%$ vs $1.0 \%)$.

In the present study, leek extract could not suppress the lipid oxidation in samples treated with EB irradiation and subsequently stored. However, our results slightly differ from those of the previous study, wherein leek extract known to be particularly rich in polyphenolic compounds was shown to inhibit the oxidation of lipids, in addition to its antimicrobial effect (Ahn et al., 2005). Further investigation is needed to explain this phenomenon.

\section{Sensory evaluation}

The pork jerky samples treated with EB irradiation and leek extract were evaluated by sensory methods (Table 4).

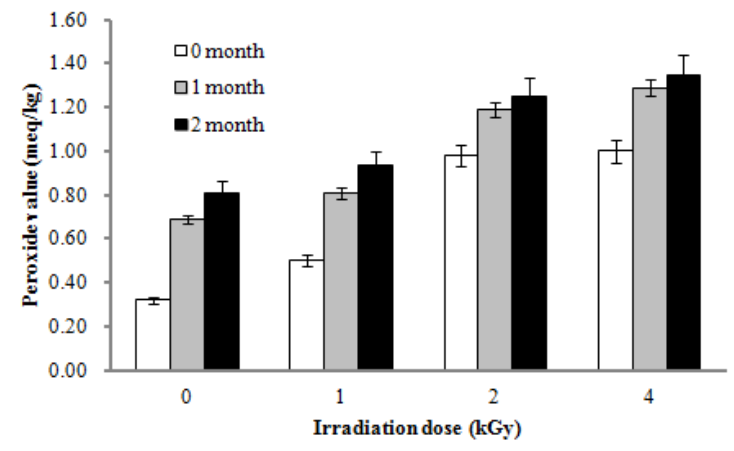

(a)

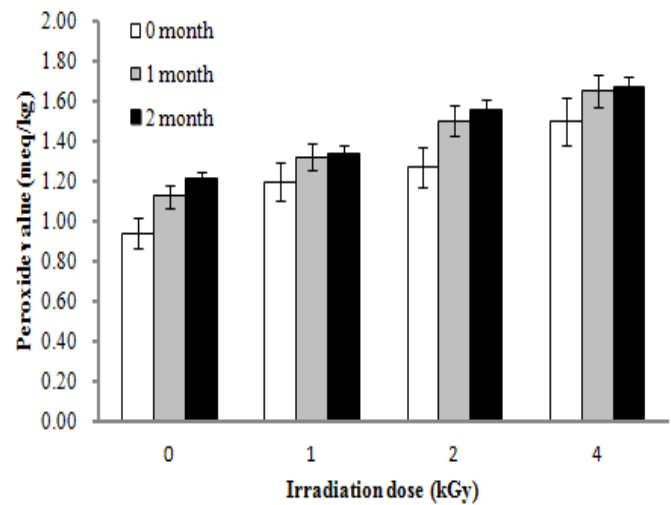

(b)

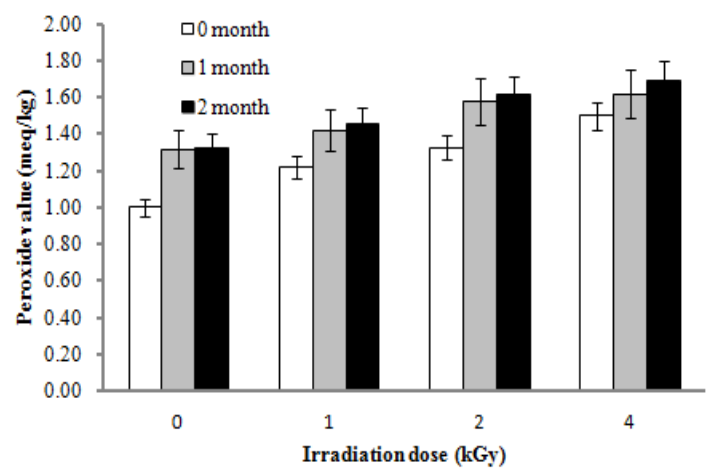

(c)

Figure 1. Effect of leek extracts ((a) $0 \%$, (b) $0.5 \%$, (c) $1.0 \%$ ) on peroxide value (meq/kg) of the electron beam-irradiated pork jerky during storage at $25^{\circ} \mathrm{C}$. 
Table 4. Sensory evaluation of the electron beam irradiated pork jerky with added leek extract

\begin{tabular}{|c|c|c|c|c|c|c|c|c|}
\hline \multirow{2}{*}{ Leek extract $(\%)$} & \multirow{2}{*}{$\begin{array}{l}\text { Irradiation } \\
\text { dose }(k G y)\end{array}$} & \multirow{2}{*}{ Color } & \multirow{2}{*}{ Flavor } & \multirow{2}{*}{ Texture } & \multirow{2}{*}{ Juiciness } & \multirow{2}{*}{$\begin{array}{c}\text { Overall } \\
\text { acceptability }\end{array}$} & \multicolumn{2}{|c|}{ Off-odor } \\
\hline & & & & & & & IR & Others \\
\hline \multirow[t]{3}{*}{$\overline{0}$} & 0 & $4.70^{\mathrm{ab}}$ & $5.70^{\mathrm{a}}$ & $4.90^{\mathrm{a}}$ & $4.80^{\mathrm{a}}$ & $5.80^{\mathrm{a}}$ & $1.40^{\mathrm{c}}$ & $1.50^{\mathrm{c}}$ \\
\hline & 2 & $5.00^{\mathrm{a}}$ & $5.80^{\mathrm{a}}$ & $5.10^{\mathrm{a}}$ & $4.70^{\mathrm{ab}}$ & $5.20^{\mathrm{a}}$ & $2.50^{\mathrm{bc}}$ & $1.70^{\mathrm{bc}}$ \\
\hline & 4 & $4.40^{\mathrm{ab}}$ & $5.30^{\mathrm{a}}$ & $4.40^{\mathrm{ab}}$ & $4.30^{\mathrm{abc}}$ & $4.90^{\mathrm{a}}$ & $3.40^{\mathrm{b}}$ & $1.40^{\mathrm{c}}$ \\
\hline \multirow[t]{3}{*}{0.5} & 0 & $4.90^{\mathrm{a}}$ & $2.90^{\mathrm{b}}$ & $3.60^{\mathrm{ab}}$ & $3.40^{\mathrm{bc}}$ & $2.30^{\mathrm{b}}$ & $2.10^{\mathrm{bc}}$ & $2.80^{\mathrm{abc}}$ \\
\hline & 2 & $4.10^{\mathrm{ab}}$ & $3.20^{\mathrm{b}}$ & $4.60^{\mathrm{a}}$ & $3.80^{\mathrm{abc}}$ & $2.80^{\mathrm{b}}$ & $3.20^{\mathrm{b}}$ & $3.10^{\mathrm{abc}}$ \\
\hline & 4 & $4.20^{\mathrm{ab}}$ & $2.60^{\mathrm{b}}$ & $3.70^{\mathrm{ab}}$ & $3.60^{\mathrm{abc}}$ & $2.70^{\mathrm{b}}$ & $5.70^{\mathrm{a}}$ & $3.40^{\mathrm{ab}}$ \\
\hline \multirow[t]{4}{*}{1.0} & 0 & $3.70^{\mathrm{b}}$ & $2.20^{\mathrm{b}}$ & $3.80^{\mathrm{ab}}$ & $3.30^{\mathrm{c}}$ & $1.80^{\mathrm{b}}$ & $2.20^{\mathrm{bc}}$ & $4.20^{\mathrm{a}}$ \\
\hline & 2 & $3.60^{\mathrm{b}}$ & $2.30^{\mathrm{b}}$ & $3.80^{\mathrm{ab}}$ & $3.50^{\mathrm{bc}}$ & $1.70^{\mathrm{b}}$ & $3.30^{\mathrm{b}}$ & $3.70^{\mathrm{a}}$ \\
\hline & 4 & $3.90^{\mathrm{ab}}$ & $2.20^{\mathrm{b}}$ & $3.10^{\mathrm{b}}$ & $3.40^{\mathrm{bc}}$ & $1.60^{\mathrm{b}}$ & $3.40^{\mathrm{b}}$ & $3.60^{\mathrm{a}}$ \\
\hline & SEM $^{1}$ & 0.515 & 0.549 & 0.654 & 0.573 & 0.562 & 0.730 & 0.800 \\
\hline
\end{tabular}

${ }^{a-c}$ Means within the same column with different superscript differ significantly $(p<0.05)$.

${ }^{1}$ Standard errors of the mean $(n=27)$.

EB irradiation of pork jerky influenced several sensory parameters. The scores of color, texture, and juiciness were lower than those of non-irradiated samples, and the scores were found to be even lower when irradiation dose was increased. The sensory scores of control related to flavor and overall acceptability were higher than those of samples treated with leek extract.

Off-odor was detected in pork jerky samples following irradiation and leek extract addition. During irradiation, free radicals are produced, and these free radicals consequently trigger lipid and/or protein oxidation. Free radicals, the precursors of lipid hydroperoxides are regarded as primary oxidation products, which further lead to the production of secondary oxidation products (alkanes, alkenes, aldehydes, alcohols, ketones, and acids) (Nawar, 1985) that have been sensorially described as "fishy", "metallic", "rancid", and "oxidized" (Kochhar, 1996). Volatile sulfur compounds of leek have been suggested to be the source of the off-odor (Park et al., 1998; Fan et al., 2002).

Therefore, by taking into consideration the influence of both EB irradiation and leek extract on several sensory parameters, novel processing methods in order to decrease the sensory changes are warranted. Recently, several studies demonstrated that certain flavors such as mint, citrus, as well as the smoky flavor of barbecue, were not influenced by irradiation and instead masked the off-flavor produced at high irradiation doses. This method was successfully applied to the production of irradiated ice cream and pork jerky without any off-flavor (Kim et al., 2007; Kim et al., 2012).

In conclusion, our findings suggest the use of EB irradiation in combination with leek extract to improve the microbiological safety of pork jerky. However, novel processing methods in order to inhibit or minimize the physicochemical and sensorial quality changes of irradiated pork jerky need to be developed as a prerequisite for industrial applicability.

\section{ACKNOWLEDGEMENTS}

This work was carried out with the support of Technology Development Program, Ministry for Food Agriculture, Forestry, and Fishery, Korea.

\section{REFERENCES}

Ahn, J., I. U. Grun and A. Mustapha. 2007. Effects of plant extracts on microbial growth, color change, and lipid oxidation in cooked beef. Food Microbiol. 24:7-14.

Ahn, M. S., H. J. Kim and M. S. Seo. 2005. The antioxidative and antimicrobial activities of the three species of leek (Allium tuberosum R.) ethanol extracts. Korean J. Food Culture 20:186-193.

Calicioglu, M., J. N., Sofos and P. A. Kendall. 2003. Influence of marinades on survival during storage of acid-adapted and nonadapted Listeria monocytogenes inoculated post-drying on beef jerky. Int. J. Food Microbiol. 86:283-292.

Chawla, S. P., R. Chander and A. Sharma. 2006. Safe and shelfstable natural casing using hurdle technology. Food Control 17:127-131.

Chen, W. S., D. C. Liu and M. T. Chen. 2004. Determination of quality changes throughout processing steps in Chinese-style pork jerky. Asian-Aust. J. Anim. Sci. 17:700-704.

Cho, K. R. 2010. Quality characteristics of sponge cake added with leek (Allium thberosum Rottler) powder. Korean J. Food Nutr. 23:478-484.

Conner, D. E. 1993. Naturally occurring compounds. In: Antimicrobials and Foods (Ed. P. M. Davidson and A. L. Branem). Dekker: New York. USA. pp. 441-468.

El-Alim, S. S. L. A., A. Lugasi, J. Hóvári and E. Dworschák. 1999. Culinary herbs inhibit lipid oxidation in raw and cooked minced meat patties during storage. J. Sci. Food Agric. 79:277285.

Fan, X., C. H. Sommers, D. W. Thayers and S. J. Lehotay. 2002. Volatile sulfur compounds in irradiated precooked turkey 
breast analyzed with pulsed flame photometric detection. J. Agric. Food Chem. 50:4257-4261.

Folch, J., M. Lee and S. G. H. Stanley. 1957. A simple method for the isolation and purification of total lipids from animal tissues. J. Biol. Chem. 226:497-509.

Han, D. J., J. Y. Jeong, J. H. Choi, Y. S. Choi, H. Y. Kim, M. A. Lee, E. S. Lee, H. D. Paik and C. J. Kim. 2007. Effects of drying conditions on quality properties of pork jerky. Korean J. Food Sci. Ani. 27:29-34

Javanmard, M., N. Rokni, S. Bokaie and G. Shahahosseini. 2006. Effects of gamma irradiation and frozen storage on microbial, chemical and sensory quality of chicken meat in Iran. Food Control 17:469-473.

Kanatt, S. R., S. P. Chawla, R. Chander and A. Sharma. 2006. Development of shelf-stable, ready-to-eat (RTE) shrimps (Penaeus indicus) using $\gamma$-irradiation as one of the hurdles. LWT-Food Sci. Technol. 39:621-626.

Keene, W. E., E. Sazie, J. Kok, D. H. Rice, D. D. Hancock, V. K. Balan, T. Zhao and M. P. Doyle. 1997. An outbreak of Escherichia coli $\mathrm{O} 157: \mathrm{H} 7$ infections traced to jerky made from deer meat. J. Am. Med. Assoc. 227:1229-1231.

Kim, H. J., A. Jang, J. S. Ham, S. G. Jeong, J. N. Ahn, M. W. Byun and C. Jo. 2007. Development of ice cream with improved microbiological safety and acceptable organoleptic quality using irradiation. J. Anim. Sci. Technol. 49:515-522.

Kim, H. J., M. Kang and C. Jo. 2012. Combined effects of electron beam irradiation and addition of onion peel extracts and flavoring on microbial and sensorial quality of pork jerky. CNU J. Agric. Sci. 39:341-347.

Kochhar, S. P. 1996. Oxidation pathways to the formulation of offflavours. In: Food Taints and Off-flavours, 2nd eds) Balckie Academic \& Professional. London. pp. 168-225.

Labuza, T. P. 1980. The effect of water activity on reaction kinetics of food deterioration. Food Technol. 34:36-41.

Leistner, L. 1987. Shelf stable product and intermediate moisture foods based on meat. In: Water activity theory and application to food (Ed. L. Rockland and L. R. Beuchat). Marcel Dekker Inc., New York. pp. 295-328.

Levine, P., B. Rose, S. Green, G. Ransom and W. Hill. 2001. Pathogen testing of ready-to-eat meat and poultry products collected at federally inspected establishments in the United States, 1990 to 1999. J. Food Prot. 64:1188-1193.

Lim, E. J., C. O. Huh, S. H. Kwon, B. S. Yi, K. R. Cho, S. G. Shin, S. Y. Kim and J. Y. Kim. 2009. Physical and sensory characteristics of cookies with added leek (Allium thberosum Rottler) powder. Korean J. Food Nutr. 22:1-7.

Lobaton-Sulabo, A. S., T. J. Axman, K. J. Getty, E. A. Boyle, N. M. Harper, K. K. Uppal, B. Barry and J. J. Higgins. 2011. Package systems and storage times serve as postlethality controls for Listeria monocytogenes on whole-muscle beef jerky and pork and beef smoked sausage sticks. J. Food Prot. 74:188-192.
Nam, K. C., K. Y. Ko, B. R. Min, H. Ismail, E. J. Lee, J. Cordray and D. U. Ahn. 2006. Influence of rosemarytocophrol/packaging combination on meat quality and the survival of pathogens in restructured irradiated pork loins. Meat Sci. 74:380-387.

Nawar, W. W. 1985. Lipids. In: Food Chemistry, 2nd eds) Revised and expanded. Marcel Dekker, New York. pp. 139-244.

Ouattara, B., S. F. Sabato and M. Lacroix. 2001. Combined effect of antimicrobial coating and gamma irradiation on shelf life extension of pre-cooked shrimp (Penaeus spp.). Int. J. Food Microbiol. 68:1-9.

Oussalah, M., S. Caillet, L. Saucier and M. Lacroix. 2007. Inhibitory effects of selected plant essential oils on the growth of four pathogenic bacteria: E. coli O157:H7, Salmonella Typhimurium, Staphylococcus aureus and Listeria monocytogenes. Food Control 18:414-420.

Park, C. J., M. L. Kim and C. S. Park. 2009. Effect of drying method and medicinal herb extract addition on the microstructure of beef jerky. Korean J. Food Preserv. 16:875883

Park, E. R., J. O. Jo, S. M. Kim, M. Y. Lee and K. S. Kim. 1998. Volatile flavor components of leek (Allium tuberosum Rottler). J. Korean Soc. Food Sci. Nutr. 27:563-567.

Park, S. Y., B. Y. Kim, H. H. Song and S. D. Ha. 2012. The synergistic effects of combined $\mathrm{NaOCl}$, gamma irradiation and vitamin $\mathrm{B}_{1}$ on populations of Aeromonas hydrophila in squid. Food Control 27:194-199.

Quattara, B., M. Giroux, R. Myefsah, W. Smoragiewicz, L. Saucier, J. Borsa and M. Lacroix. 2002. Microbiological and biochemical characteristics of ground beef as affected by gamma irradiation, food additives and edible coating film. Radiat. Phys. Chem. 63:299-304.

Rockland, L. B. and S. K. Nishi. 1980. Influence of water activity on food product quality and stability. Food Technol. 34:42-51.

USDA/FSIS (US Department of Agriculture-Food Safety and Inspection Service). 2003. New Mexico firm recalls beef jerky for possible Salmonella contamination. FSIS New Releases, October 2.

Yamaguchi, N., S. Naito, Y. Okada and A. Nagase. 1986. Effect of oxygen barrier of packaging material on food preservation. Annual Report of the Food Research Institute, 27, Japan: Aichi Prefecture Government. pp. 69-73.

Yang, C. Y. and S. H. Lee. 2002. Evaluation of quality of the marketing jerky in domestic (1. Investigation of outward appearance, food additives, nutrient content and sanitary state). Korean J. Food Nutr. 15:197-202.

Yang, H. S., Y. H. Hwang, S. T. Joo and G. B. Park. 2009. The physicochemical and microbiological characteristics of pork jerky in comparison to beef jerky. Meat Sci. 82:289-294.

Yun, H., M. Lacroix, S. Jung, K. Kim, J. W. Lee and C. Jo. 2011. Effect of several food ingredients on radiation inactivation of Escherichia coli and Listeria monocytogenes inoculated into ground pork. Radiat. Phys. Chem. 80:994-997. 